\title{
Folliculogenesis and ovarian expression of mRNA encoding aromatase in anoestrous sheep after 5 days of glucose or glucosamine infusion or supplementary lupin feeding
}

\author{
M. Muñoz-Gutiérrez ${ }^{1,3}$, D. Blache², G. B. Martin² \\ and R. J. Scaramuzzi ${ }^{1}$ \\ ${ }^{1}$ Department of Veterinary Basic Sciences, Royal Veterinary College, University of London, \\ Royal College Street, London NW1 OTU, UK; ${ }^{2}$ Department of Animal Science and \\ Production, University of Western Australia, Nedlands 6000, Western Australia, Australia; \\ and ${ }^{3}$ Departamento de Biología de la Reproducción, Universidad Autónoma Metropolitana \\ Iztapalapa, Mexico City, Mexico
}

Improved nutrition increases ovulation rate in sheep and there is evidence that intra-ovarian pathways mediate responses to nutrition. An experiment was conducted to examine the effect of dietary energy on folliculogenesis. Anoestrous Merino ewes were fed a diet of wheat straw alone (control, $n=5$ ), or wheat straw supplemented with lupins $\left(500 \mathrm{~g} \mathrm{day}^{-1}, n=5\right)$. Other ewes were fed wheat straw and infused with glucose $\left(50 \mathrm{mmol} \mathrm{h}^{-1}, n=5\right)$ or with glucosamine $\left(3.5 \mathrm{mmol} \mathrm{h}^{-1}, n=5\right)$. Intravaginal progestagen sponges were inserted for 12 days, and nutritional treatments were started 5 days before sponge removal. At sponge removal, the ewes were injected with a regimen of GnRH pulses (500 ng every $4 \mathrm{~h}$ from 0 to $12 \mathrm{~h}$; $250 \mathrm{ng}$ every $2 \mathrm{~h}$ from 14 to $24 \mathrm{~h}$; and $200 \mathrm{ng}$ every $1 \mathrm{~h}$ from 25 to $36 \mathrm{~h}$ ) to simulate normal follicular development. Thirty-six hours after sponge removal, the animals were killed and the ovaries were collected and stored at $-\mathbf{8 0}^{\circ} \mathrm{C}$. The ovaries were sectioned serially every $10 \mu \mathrm{m}$. Every 20th section was stained (to estimate number and diameter of follicles) and every 17-19th section was

\section{Introduction}

Nutrition is a major factor determining the ovulation rate in domestic animals (Lindsay et al., 1991) and the effect of nutrition is thought to be associated with alterations in the metabolic signals that mediate energy availability (Rhind and McNeilly, 1986; Rhind et al., 1989; Downing, 1994). Ovulation rate is determined ultimately by the mechanism that controls selection of the ovulatory follicles from the follicular cohort. This mechanism is characterized by the complex relationship between intrafollicular growth factors and the hypothalamo-pituitary-ovarian feedback system during the final stages of follicular growth and development (Skinner et al., 1987; Lobb and Dorrington,

Email: mmunoz@rvc.ac.uk probed by in situ hybridization for $\mathbf{P}_{450}$ aromatase. Data were analysed using ANOVA and chi-squared tests. There was an effect of treatment $(P<0.05)$ on the number of follicles 2-3, 3-4 and 6-7 mm in diameter. Aromatasepositive follicles $(1.6-7.9 \mathrm{~mm})$ were detected in 31 follicles from 15 ewes across all four groups. In ten animals, the largest follicle was aromatase-positive. The diameters of aromatase-positive follicles were larger $(P=0.004)$ in lupin fed compared with glucose-infused ewes $(4.9 \pm 0.5,3.6 \pm 0.7,5.3 \pm 0.5$ and $4.2 \pm 0.5 \mathrm{~mm}$ for control, glucose-infused, lupin-fed and glucosamineinfused groups, respectively). Treatment did not affect the plasma concentration of $\mathrm{FSH}$ when compared with controls, indicating that the energy supplements were modifying recruited (2-3 $\mathrm{mm}$ and $3-4 \mathrm{~mm}$ ) and selected follicles $(>6 \mathrm{~mm})$ directly. In conclusion, dietary energy can directly stimulate folliculogenesis in recruited and selected follicles, and this effect may be mediated by changes in systemic leptin concentrations and the hexosamine energy-sensing pathway in the follicle.
1992; Scaramuzzi et al., 1993; Monniaux et al., 1994; Monget and Monniaux, 1995; Bao and Garverick, 1998).

An increase in the supply of energy can stimulate follicle development and increase ovulation rate in sheep. Ovulation rate is increased by the infusion of glucose into either the abomasum (Landau et al., 1995) or the jugular vein (Downing et al., 1995a), by the infusion of a mixture of branched chain amino acids into the jugular vein (Downing et al., 1995b) and by dietary supplementation with lupin grain (Nottle et al., 1988, 1990; Downing et al., 1995c). All of these treatments also increase peripheral insulin concentrations (Downing et al., 1995a,b,c), indicating that insulin-mediated glucose uptake, possibly by the ovary, modulates nutritional effects on ovulation rate. In support of this contention, the insulin-dependent glucose transporter 
(GLUT4) is present in both theca and granulosa cells of antral follicles in ewes (Williams et al., 2001). An increase in the supply of energy substrates in this manner is thought to either promote the growth and development of follicles that would not normally ovulate or restore the ovulatory capacity of previously compromised follicles.

The mechanism that transduces this energetic input into a reproductive response in the ovary is not clear. The energy demands for folliculogenesis are minimal, so it is not the supply of energy per se that is responsible for this effect. A mechanism based on changes in hypothalamo-pituitary feedback is also unlikely because studies have been unable to establish a link between plasma FSH concentrations and ovulation rate (Findlay and Cumming, 1976; Bindon et al., 1979; Cahill et al., 1981; Driancourt et al., 1988; Downing and Scaramuzzi, 1991). The direct action of a nutrient or metabolite on the follicle is a current theory and two potential mechanisms are leptin signalling in the follicle and nutrient sensing via the hexosamine biosynthetic pathway.

Leptin is a protein produced by adipose tissue and is involved in the regulation of appetite, energy expenditure and whole-body energy balance (Ingvarsten and Boisclair, 2001). Leptin also affects the reproductive system, acting either at the hypothalamus-pituitary axis, where it appears to help maintain adequate gonadotrophin secretion or by a direct action on the follicular granulosa cells (Spicer, 2001). Thus, in cultured bovine granulosa cells, leptin inhibits oestradiol production (Spicer and Francisco, 1997; B. K. Campbell, unpublished).

The hexosamine biosynthetic pathway can quantitatively assess metabolic status and act as a signalling pathway in some tissues (Wang et al., 1998). Thus, tissues such as skeletal muscle and adipose tissue assess nutritional status so that they can respond to short-term variation in nutritional flux. Intracellular glucose enters the pathway as fructose 1,6-diphosphate and glucosamine is an intermediate in this pathway. One consequence of increased glucose flux through the hexosamine pathway in muscle is the increased expression of genes for leptin (Wang et al., 1998) and two growth factors, fibroblast growth factor 2 (FGF2) (McClain et al., 1992) and transforming growth factor $\alpha$ (TGF- $\alpha$ ) (Daniels et al., 1993; Roos et al., 1996), which are potent regulators of granulosa cell proliferation and steroidogenesis (Gospodarowicz et al., 1977; Gospodarowicz and Bialecki, 1979; Adashi et al., 1987, 1988; Skinner and Coffey, 1988).

These potential roles of leptin as a nutritional mediator of follicular function and the hexosamine pathway as a follicular energy sensing mechanism have not been demonstrated. Therefore, the present study tested the hypotheses that: (i) short-term nutritional treatments that stimulate folliculogenesis will increase plasma leptin concentrations; and (ii) increased concentrations of glucose or glucosamine acting through the hexosamine biosynthetic pathway increase the number of follicles positive for aromatase gene expression.

\section{Materials and Methods}

\section{Animals and treatments}

Twenty-one adult anoestrous Merino ewes were treated for 12 days with medroxyprogesterone sponges (Repromap; Upjohn, Rydalmare). At the same time, the animals were allocated randomly to one of four treatment groups: (i) basal straw diet plus jugular i.v. saline infusion (control group, $n=5$ ); (ii) basal straw diet plus $50 \mathrm{mmol}$ glucose $\mathrm{h}^{-1}$ by jugular intravenous infusion $(n=5)$; (iii) basal straw diet plus $500 \mathrm{~g}$ lupin grain day ${ }^{-1}(n=6)$; and (iv) basal straw diet plus $3.5 \mathrm{mmol}$ glucosamine $\mathrm{h}^{-1}$ by jugular intravenous infusion $(n=5)$. The nutritional treatments lasted for $120 \mathrm{~h}$ and ended at the time of sponge removal. The day before the experiment started, bilateral jugular venous cannulae were inserted under xylocaine-induced local anaesthesia. One catheter was used exclusively for infusions and the other for collecting blood samples.

An artificial follicular phase to simulate normal follicular development was induced, using a regimen of treatment with $\mathrm{GnRH}$. Starting at sponge removal, each ewe was treated with a regimen of intravenous pulses of $\mathrm{GnRH}$ (Sigma, St Louis, MO). The pulses were administered in three stages: 500 ng every $4 \mathrm{~h}$ from 0 to $12 \mathrm{~h}$; 250 ng every $2 \mathrm{~h}$ from 14 to $24 \mathrm{~h}$; and $200 \mathrm{ng}$ every $1 \mathrm{~h}$ from 25 to $36 \mathrm{~h}$. The animals were then killed with an overdose (5-6 g) of intravenous pentobarbital $156 \mathrm{~h}$ after the start of nutritional treatments and $36 \mathrm{~h}$ after sponge removal. Bilateral samples of ovarian venous blood $(2-5 \mathrm{ml})$ were taken immediately and the ovaries were removed and stored at $-80^{\circ} \mathrm{C}$.

\section{Collection of blood samples and hormone analysis}

Concentrations of FSH, leptin, glucose and insulin were determined every $8 \mathrm{~h}$ starting $24 \mathrm{~h}$ before the commencement of nutritional treatments and continuing to the end of the experiment. Glucose was measured in whole blood using a Medisense ${ }^{\circledR} 2$ glucose meter (Medisense Inc., Bedford, MA). The normal reading range was $1.1-33.3 \mathrm{mmol} \mathrm{I}^{-1}$. Coefficients of variation (CV) for fresh human blood for low $\left(2.2 \pm 0.2 \mathrm{mmol} \mathrm{I}^{-1}\right)$ medium $\left(4.5 \pm 0.2 \mathrm{mmol} \mathrm{I}^{-1}\right)$ high-medium $\left(11.1 \pm 0.4 \mathrm{mmol} \mathrm{I}^{-1}\right)$ and high $\left(14.2 \pm 0.7 \mathrm{mmol} \mathrm{I}^{-1}\right)$ quality controls were 7.7, 4.1, 3.1 and 4.7\%, respectively (Williams et al., 2001). Blood was centrifuged at $1500 \mathrm{~g}$ for $10 \mathrm{~min}$ and the plasma was recovered and stored at $-20^{\circ} \mathrm{C}$. Total oestrogen concentrations were measured in ovarian venous blood, and $\mathrm{FSH}$, insulin and leptin concentrations were measured in jugular venous blood using validated radioimmunoassays. Total plasma oestrogen was measured by radioimmunoassay based on the method of Webb et al. (1985). The total oestrogen concentration was measured in plasma after extraction of the samples with $4 \mathrm{ml}$ ethyl acetate:hexane $(3: 2)$. The extract was redissolved in $0.10 \mathrm{ml}$ gelatinphosphate buffer and incubated overnight at $4^{\circ} \mathrm{C}$ with $0.10 \mathrm{ml}$ antiserum (anti-Total Estrogens 1000T; ICN Biomedicals, CA) at a working dilution of 1:15000. 
lodinated tracer $(0.10 \mathrm{ml}$ containing 10000 d.p.m. 1,2,6,7$\left[\mathrm{H}^{3}\right]$ oestradiol) was added and the mixture incubated overnight at $4^{\circ} \mathrm{C}$. Bound and free tracer were separated by incubating the assay mixture with $0.5 \mathrm{ml}$ charcoal $(0.5 \%)$ coated with dextran $(0.05 \%)$ at $4^{\circ} \mathrm{C}$ and centrifuged at 3000 r.p.m. The major crossreactions of the antiserum are oestradiol $(100 \%)$, oestrone $(100 \%)$, oestrone-sulphate $(60 \%)$, oestradiol $-17 \alpha(7 \%)$ and oestriol $(415 \%)$. The limit of detection was $1.1 \mathrm{pg} \mathrm{ml}^{-1}$. All the samples were measured in one assay for which the intra-assay CV was $4.7 \%$ at $7.4 \mathrm{pg} \mathrm{ml}^{-1}, 5.0 \%$ at $19 \mathrm{pg} \mathrm{ml}^{-1}$ and $4.4 \%$ at $32 \mathrm{pg} \mathrm{ml}^{-1}$. Plasma was assayed for FSH in duplicate by a doubleantibody radioimmunoassay (Atkinson and Adams, 1988) using NIAMDD-oFSH-RP-1 (bio-potency $75 \times \mathrm{NIH}-\mathrm{FSH}$ S1) and NIADDK-anti-oFSH-1 serum. Plasma insulin concentrations were measured in duplicate by double-antibody radioimmunoassay (Tindal et al., 1978). The samples were assayed as duplicate $200 \mu \mathrm{l}$ aliquots. A specific radioimmunoassay based on recombinant bovine leptin with an antiserum raised in an emu (Dromaius novaehollandiae) (Blache et al., 2000) was used to measure leptin. Briefly, triplicates of standards and duplicates of unknown samples were incubated overnight at $4^{\circ} \mathrm{C}$ with diluted antiserum and normal emu serum and then incubated with labelled leptin for $48 \mathrm{~h}$ at $4^{\circ} \mathrm{C}$. After incubation, diluted sheep anti-emu serum was added and the tubes were again incubated for $48 \mathrm{~h}$ at $4^{\circ} \mathrm{C}$. Polyethylene glycol 6000 was added to the tubes before centrifugation. The limit of detection was $100 \mathrm{pg} \mathrm{ml}^{-1}$ and the intra-assay coefficient of variation was $6.5 \%$ at a bound:free ratio of $65 \%$.

The minimum detectable concentrations of FSH, insulin, leptin and oestradiol were $0.44 \mathrm{ng} \mathrm{ml}^{-1}, 4.5 \mu \mathrm{U} \mathrm{ml}-1$, $0.2 \mathrm{mg} \mathrm{ml}^{-1}$ and $1.0 \mathrm{pg} \mathrm{ml}^{-1}$, respectively. The intra-assay CVs were $3.4,7.3,0.79$ and $4.3 \%$ for $\mathrm{FSH}$, insulin, leptin and oestradiol, respectively.

\section{Number of follicles}

The frozen ovaries of 21 animals (42 ovaries) were sectioned serially at $10 \mu \mathrm{m}$ intervals using a cryostat. The frozen sections were mounted on to glass slides (2-3 sections per slide) and fixed. The fixed slides were stored in $95 \%$ alcohol at $4^{\circ} \mathrm{C}$. The number of follicles was determined by counting all microscopically visible follicles on every 20th slide stained with Harris's haematoxylin and eosin. The follicular diameter was calculated from the mean of two perpendicular diameters. The follicles were classified as follows: $\mathrm{F}<1$ : follicles $<1 \mathrm{~mm}$ in diameter; $\mathrm{F} 1$ : follicles 1-2 $\mathrm{mm}$ in diameter; F2: follicles $>2-3 \mathrm{~mm}$ in diameter; F3: follicles > 3-4 $\mathrm{mm}$ in diameter; F4: follicles $>4-5 \mathrm{~mm}$ in diameter; F5: follicles $>5-6 \mathrm{~mm}$ in diameter; F6: follicles $>6-7 \mathrm{~mm}$ in diameter; and F7: $>7 \mathrm{~mm}$ in diameter.

\section{In situ hybridization}

The expression of cythocrome $P_{450}$ aromatase was determined on dehydrated and fixed sections $(10 \mu \mathrm{m})$ of frozen ovaries (Wathes et al., 1996; Leung et al., 1999). The sections were probed with $\left[\alpha^{35}\right.$ S] dATP (S) 1334; Amersham Pharmacia Biotech, Bucks) labelled DNA probes specific for $\mathrm{P}_{450}$ aromatase (antisense; $45 \mathrm{mer}$ synthetic oligonucleotide). The probe sequences were based on the published cDNA sequence for aromatase (Hinshelwood et al., 1993). The oligonucleotide 45 mers was synthesized using the specific sequence 5'-TCA CCG GGT AGC CAT CGA TGA CAT CAT CCT CTA AGG CTT TGC GCA-3' (Leung et al., 1999; Genbank accession number Z69249).

Established in situ hybridization procedures (Perks, 1994; Wathes et al., 1996; Leung, 1997) were used with minor modifications. Briefly, the sections were impregnated with the reaction mixture containing labelled probe in hybridization buffer (100000 c.p.m. per $100 \mu \mathrm{l}$ of hybridization buffer per slide), covered with a Parafilm coverslip, and incubated overnight at $42^{\circ} \mathrm{C}$. After incubation, the sections were washed at room temperature in citrate buffer (SSC; 15 mmol sodium chloride $\mathrm{I}^{-1}, 15 \mathrm{mmol}$ sodium citrate $\mathrm{I}^{-1}$, $\mathrm{pH} 7.0$, containing $0.2 \% \quad(\mathrm{w} / \mathrm{v})$ sodium thiosulphate- 5 hydrate) in a shaking bath for $30 \mathrm{~min}$ followed by $1 \mathrm{~h}$ at $60^{\circ} \mathrm{C}$. The slides were dehydrated in a gradient of ethanol, air dried and exposed to Kodak Biomax MR-1 film for 15 days. The sense probe was used as the negative control.

\section{Photographic development}

The manufacturer's (LM-1; Amersham Pharmacia Biotech) instructions were followed. Briefly, dried slides were dipped vertically into the emulsion for $5 \mathrm{~s}$ at $43^{\circ} \mathrm{C}$ and allowed to dry horizontally at room temperature and then on a metal tray pre-cooled with dry ice for $10 \mathrm{~min}$ each. The slides were then placed in a light-tight box with anhydrous silica gel in the base of the box and incubated for 3 weeks. After incubation, the slides were dipped into a developer (Phenisol; Ilford Limited, Ilford) for $5 \mathrm{~min}$ and then into a stop bath of $0.5 \%$ acetic acid (v/v) for $1 \mathrm{~min}$. The developed slides were immersed in a fixative $(47 \%(\mathrm{w} / \mathrm{v})$, sodium thiosulphate pentahydrate) for $10 \mathrm{~min}$ and finally into distilled water for at least 10 min before counterstaining with Harris' haematoxylin and eosin.

\section{Image analysis}

After exposure, the photographic images of the ovarian sections were quantified for specific labelling using an image analysis system (Seescan, Cambridge) to measure the absorbance of specific areas (granulosal layer) identified on adjacent slides. The emulsion-coated slides were also used to confirm the cellular localization of the aromatase signal. The results from the autoradiographs were expressed as arbitrary units of absorbance with a linear range of 0.01-2.10. The non-specific counts (estimated from the sense probe) were subtracted from the total counts (estimated from the anti-sense probe) to produce a mean value for the specific hybridization in each follicle.

\section{Statistical analyses}

The concentrations of FSH, leptin, glucose and insulin were analysed for time and treatment effects using a split- 
Table 1. Number (mean \pm SEM) and size distribution of follicles in eight diameter classes of GnRHtreated anoestrous Merino ewes infused with glucose or glucosamine, or fed a supplement of lupin grain for 5 days

\begin{tabular}{lcccc}
\hline $\begin{array}{l}\text { Follicle class } \\
\text { (diameter, mm) }\end{array}$ & Control & Glucose & Lupin grain & Glucosamine \\
\hline F0 $(<1)$ & $36.7 \pm 2.8$ & $46.6 \pm 9.1$ & $42.7 \pm 6.62$ & $38.8 \pm 10.3$ \\
F1 (1-2) & $15.5 \pm 2.2$ & $24.4 \pm 5.4$ & $22.0 \pm 5.9$ & $15.8 \pm 3.7$ \\
F2 (2-3) & $4.1 \pm 1.7^{\mathrm{a}}$ & $8.2 \pm 3.4^{\mathrm{b}}$ & $2.7 \pm 0.4^{\mathrm{c}}$ & $5.6 \pm 1.9^{\mathrm{a}}$ \\
F3 (3-4) & $0.6 \pm 0.3^{\mathrm{a}}$ & $2.6 \pm 1.6^{\mathrm{b}}$ & $1.7 \pm 0.2^{\mathrm{b}}$ & $2.0 \pm 0.6^{\mathrm{c}}$ \\
F4 (4-5) & $1.3 \pm 0.5$ & $1.2 \pm 0.2$ & $0.5 \pm 0.3$ & $1.6 \pm 0.5$ \\
F5 (5-6) & $1.1 \pm 0.3$ & $0.6 \pm 2.4$ & $1.2 \pm 0.2$ & $0.6 \pm 0.2$ \\
F6 (6-7) & $0^{\mathrm{a}}$ & $0.2 \pm 0.2^{\mathrm{a}, \mathrm{b}}$ & $0.7 \pm 0.2^{\mathrm{b}}$ & $0.2 \pm 0.2^{\mathrm{a}, \mathrm{b}}$ \\
F7 $(>7)$ & 0 & $0.2 \pm 0.2$ & 0 & 0 \\
\hline
\end{tabular}

Values with different superscripts within rows differ significantly $(P<0.05)$.

plot ANOVA. Post-hoc differences between treatment groups were further examined using Tukey's test (SAS, 1995). Chisquared tests were used to determine differences in the size distribution of follicles and to identify any differences in the number of follicles positive to $\mathrm{P}_{450}$ aromatase.

\section{Results}

One animal in the lupin-fed group had an infected uterus and a persistent corpus luteum. This animal was excluded from the results and analyses.

\section{Number and distribution of ovarian follicles}

The mean number of follicles in each class decreased as average follicle size increased (Table 1). There was no effect of treatment on the number of follicles in the $<1 \mathrm{~mm}$, 1-2 $\mathrm{mm}, 4-5 \mathrm{~mm}$ and 5-6 $\mathrm{mm}$ size classes. However, there were significant effects of treatment on follicles in the 2-3 mm, 3-4 and 6-7 mm classes ( $P<0.05$; Table 1).

There were effects of the nutritional supplements on both medium-sized (2-3 $\mathrm{mm}$ and 3-4 $\mathrm{mm}$ ) and large $(6-7 \mathrm{~mm})$ follicles. Lupin-fed ewes had fewer follicles $2-3 \mathrm{~mm}$ in diameter $(P<0.05)$, whereas glucose-infused ewes had more follicles in this class $(P<0.01)$ compared with control and glucosamine-infused ewes. However, for follicles of 3-4 $\mathrm{mm}$ in diameter, all treated groups had more follicles than the control group. Follicles $>6 \mathrm{~mm}$ in diameter were found only in nutritionally supplemented ewes. The lupinfed group had significantly more follicles of $6-7 \mathrm{~mm}$ in diameter than did the control group $(P<0.05)$.

\section{Ovarian $P_{450}$ aromatase expression}

Aromatase expression was confirmed in the granulosa cell layer (Fig. 1) and the concentration of mRNA in aromatase-positive follicles was not affected by treatment (Table 2). Nutritionally stimulated ewes tended to have more aromatase-positive follicles than did the control ewes but the differences were not significant (Table 2). However, when the treated groups were pooled and the data reanalysed, the difference was significant (control $0.8 \pm 0.37$ and pooled-treated $1.92 \pm 0.35$ aromatase-positive follicles per ewe; $P<0.05)$.

The mean diameter of aromatase-positive follicles was affected by lupin and glucose treatments $(P<0.01$; Table 2 ). The average diameter of aromatase-positive follicles was greatest in lupin-fed ewes and smallest in glucose-infused ewes (Table 2), although differences from average diameters of aromatase-positive follicles in control or glucosamineinfused groups were not significant.

\section{Total oestrogen concentration in ovarian venous blood}

The mean concentration of oestrogen was significantly greater $(P<0.05)$ in the ovarian venous blood from ovaries containing aromatase-positive follicles $\left(46.8 \pm 12.8 \mathrm{pg} \mathrm{ml}^{-1}\right)$ compared with that in ovarian venous blood from ovaries containing aromatase-negative follicles (19.6 $\left.\pm 3.3 \mathrm{pg} \mathrm{m}^{-1}\right)$. The mean concentrations of oestrogen in ovarian venous blood were not affected by treatment (Table 2).

\section{Glucose concentration in jugular venous blood}

The mean blood concentrations of glucose were increased by glucose infusion but were not affected by the other treatments (Table 3). The mean concentration of glucose in blood increased rapidly once the glucose infusion started and remained high for the duration of the infusion. At the end of infusion, the glucose concentrations in blood fell rapidly to pre-infusion values (Fig. 2).

\section{Hormone concentration in jugular venous blood}

The mean plasma concentrations of insulin were significantly increased by glucose infusion and feeding lupins (Table 3). However, the patterns of these increases differed (Fig. 3). In the glucose-infused group, the insulin concentration was increased significantly $(P<0.05)$ by $8 \mathrm{~h}$ after the beginning of infusion and remained high $(P<0.05)$ until the end of infusion at $120 \mathrm{~h}$. In the lupin-fed group, the concen- 


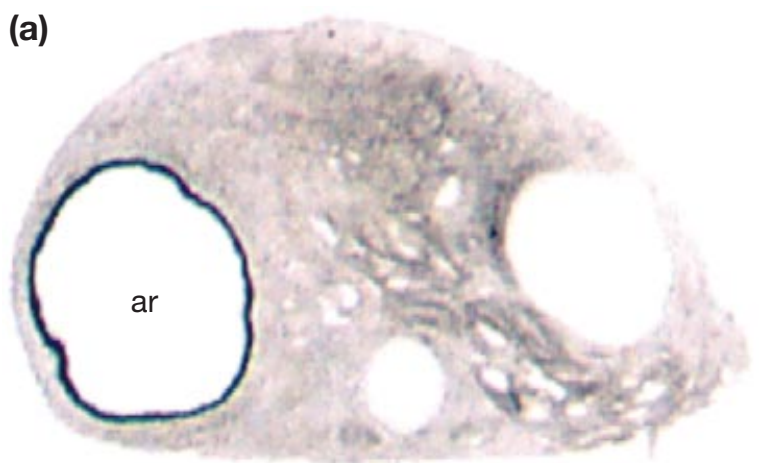

(b)


Fig. 1. (a,c,d) Antisense and (b,e,f) sense autoradiographic localization of mRNA for cytochrome $P_{450}$ aromatase in ovaries from $\mathrm{GnRH}$-stimulated anoestrous Merino ewes. Note the intense localization of aromatase mRNA in the granulosa cells and its absence in theca cells. ar: aromatase; fa: follicular antrum; g: granulosa cells; t: theca cells. Scale bars represent (a,b) $2.5 \mu \mathrm{m},(\mathrm{c}-\mathrm{e}) 10 \mu \mathrm{m}$, and (f) $5 \mu \mathrm{m}$.

tration of insulin was increased at $32 \mathrm{~h}, 80 \mathrm{~h}$ and from 96 to $120 \mathrm{~h}(P<0.05)$ after the start of lupin feeding. Concentrations of insulin in the control and glucosamine-infused groups were not different from each other (Table 3; Fig. 3).

The mean plasma concentrations of leptin were affected by treatment with significantly higher concentrations in the glucose-infused and lupin-fed groups compared with the control and glucosamine-infused groups $(P<0.05$; Table 3$)$. The pattern of response differed in the two affected groups (Fig. 4). In glucose-infused ewes, leptin concentrations increased to a maximum at $16 \mathrm{~h}$ after the start of infusion
$(P<0.05)$ and remained high for a further $32 \mathrm{~h}(P<0.05)$, after which time they returned to control concentrations (Fig. 4). In the lupin-fed group, leptin concentrations increased more slowly to a maximum at $24 \mathrm{~h}$ after the start of feeding $(P<0.05)$ and remained high for another $72 \mathrm{~h}$ $(P<0.05)$ after which they returned to control concentrations (Fig. 4).

The mean plasma concentrations of $\mathrm{FSH}$ were not affected by any treatment when compared with the control ewes (Table 3). However, the mean plasma concentration of FSH in glucosamine-infused ewes was significantly lower 
Table 2. Number and diameter of aromatase-positive follicles, aromatase (arbitrary units of absorbance) and the ovarian venous concentration of oestradiol of GnRH-treated anoestrous Merino ewes infused with glucose or glucosamine, or fed a supplement of lupin grain for 5 days

\begin{tabular}{lcccc}
\hline & $\begin{array}{c}\text { Number of } \\
\text { aromatase-positive } \\
\text { follicles per ewe }\end{array}$ & $\begin{array}{c}\text { Diameter of } \\
\text { aromatase-positive } \\
\text { follicles }(\mathrm{mm})\end{array}$ & $\begin{array}{c}\text { Aromatase mRNA } \\
\text { concentration } \\
\text { (units of absorbance) }\end{array}$ & $\begin{array}{c}\text { Total oestrogen } \\
\text { concentration in } \\
\text { ovarian venous blood } \\
\left(\mathrm{pg} \mathrm{ml} \mathbf{H}^{-1}\right)\end{array}$ \\
\hline Control & $0.8 \pm 0.3$ & $4.9 \pm 0.5^{\mathrm{a}, \mathrm{b}}$ & $0.41 \pm 0.1$ & $18.0 \pm 3.9$ \\
Glucose infusion & $2.0 \pm 0.8$ & $3.6 \pm 0.7^{\mathrm{a}}$ & $0.32 \pm 0.07$ & $39.9 \pm 18.9$ \\
Lupin fed & $2.0 \pm 0.0$ & $5.3 \pm 0.5^{\mathrm{b}}$ & $0.48 \pm 0.04$ & $37.2 \pm 9.3$ \\
Glucosamine infusion & $1.8 \pm 0.6$ & $4.2 \pm 0.5^{\mathrm{a}, \mathrm{b}}$ & $0.47 \pm 0.07$ & $40.0 \pm 29.4$ \\
\hline
\end{tabular}

Values are mean \pm SEM.

Values with different superscripts within columns differ significantly $(P<0.05)$.

Table 3. Blood concentration of glucose (mean \pm SEM) and the plasma concentrations of insulin, FSH and leptin (mean \pm SEM) of GnRHtreated anoestrous Merino ewes infused with glucose or glucosamine, or fed a supplement of lupin grain for 5 days

\begin{tabular}{|c|c|c|c|c|}
\hline Treatment & Control & Glucose infused & Lupin fed & Glucosamine infused \\
\hline Glucose $\left(\mathrm{mmol} \mathrm{l}^{-1}\right)$ & $3.4 \pm 0.04^{\mathrm{a}}$ & $4.3 \pm 0.08^{b}$ & $3.5 \pm 0.04^{\mathrm{a}}$ & $3.3 \pm 0.04^{\mathrm{a}}$ \\
\hline Insulin $\left(\mu \cup \mathrm{ml}^{-1}\right)$ & $12.7 \pm 0.8^{\mathrm{a}}$ & $33.1 \pm 2.1^{b}$ & $20.9 \pm 2.3^{c}$ & $12.7 \pm 1.2^{\mathrm{a}}$ \\
\hline Leptin (ng ml-1) & $0.5 \pm 0.01^{a}$ & $0.7 \pm 0.03^{b}$ & $0.7 \pm 0.03^{b}$ & $0.5 \pm 0.02^{\mathrm{a}}$ \\
\hline $\mathrm{FSH}\left(\mathrm{ng} \mathrm{m}^{-1}\right)$ & $1.39 \pm 0.05^{\mathrm{ab}}$ & $1.42 \pm 0.04^{\mathrm{ab}}$ & $1.46 \pm 0.06^{\mathrm{a}}$ & $1.29 \pm 0.04^{b}$ \\
\hline
\end{tabular}

Values with different superscripts within rows differ significantly $(P<0.05)$.

Glucose, FSH and leptin showed an effect of day of treatment $(P<0.05)$.

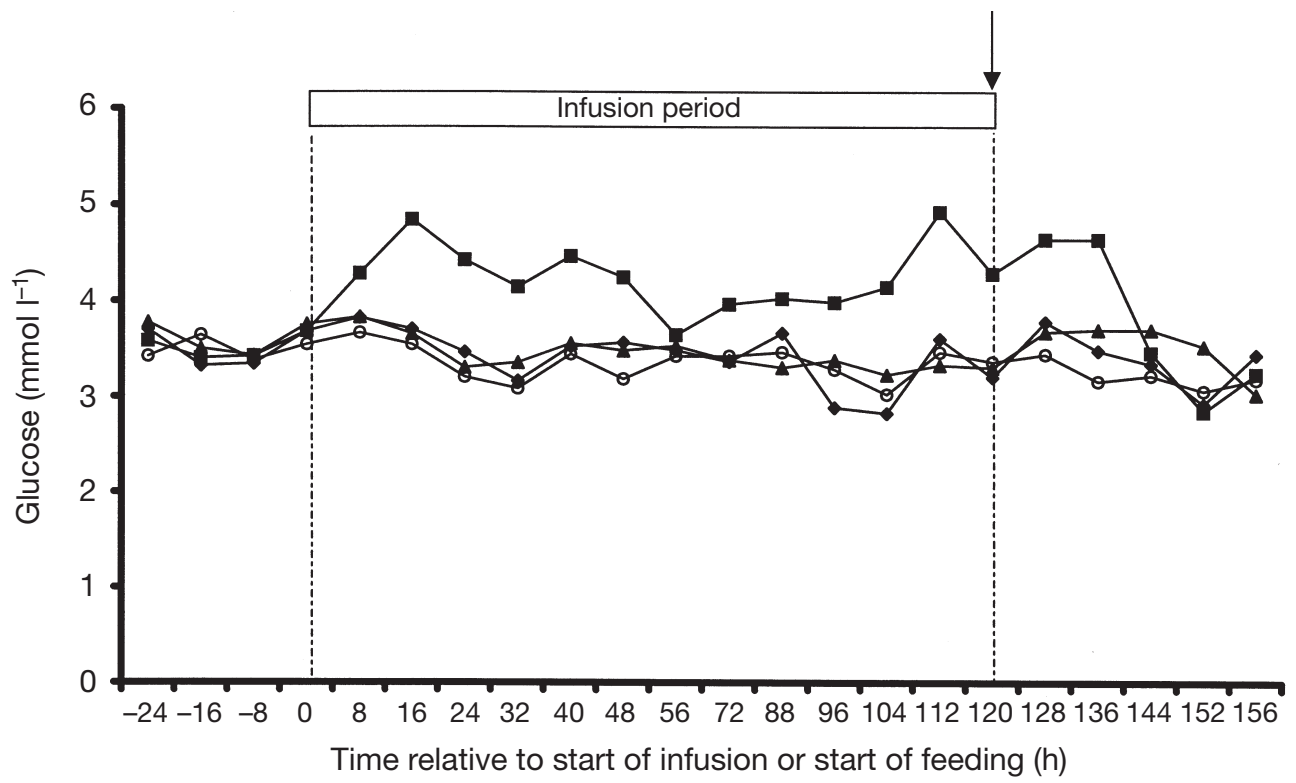

Fig. 2. Mean blood concentration of glucose in anoestrous Merino ewes in which follicular growth was induced with a regimen of GnRH. Ewes were infused with saline (control, $\bullet ; n=5$ ), glucose

$\left(\boldsymbol{\square}, 50 \mathrm{mmol} \mathrm{h}^{-1} ; n=5\right)$ or glucosamine $\left(\bigcirc, 3.5 \mathrm{mmol} \mathrm{h}^{-1} ; n=5\right)$ or fed a supplement of lupin grain $\left(\boldsymbol{\Lambda}, 500 \mathrm{~g} \mathrm{day}^{-1} ; n=4\right)$ for 5 days until the time of progesterone pessary withdrawal (arrow). Animals were killed $156 \mathrm{~h}$ after the start of infusion or feeding.

than it was in the lupin-fed ewes $(P<0.05$; Table 3$)$. There was a significant effect of time $(P<0.05)$ on plasma FSH concentrations (Fig. 5) and FSH declined significantly in all groups after the withdrawal of progestagen sponges at the end of the infusions.

\section{Discussion}

The regimen of $\mathrm{GnRH}$ injections used in the present study could simulate normal development of follicles in anoestrous ewes, and aromatase-positive follicles were 


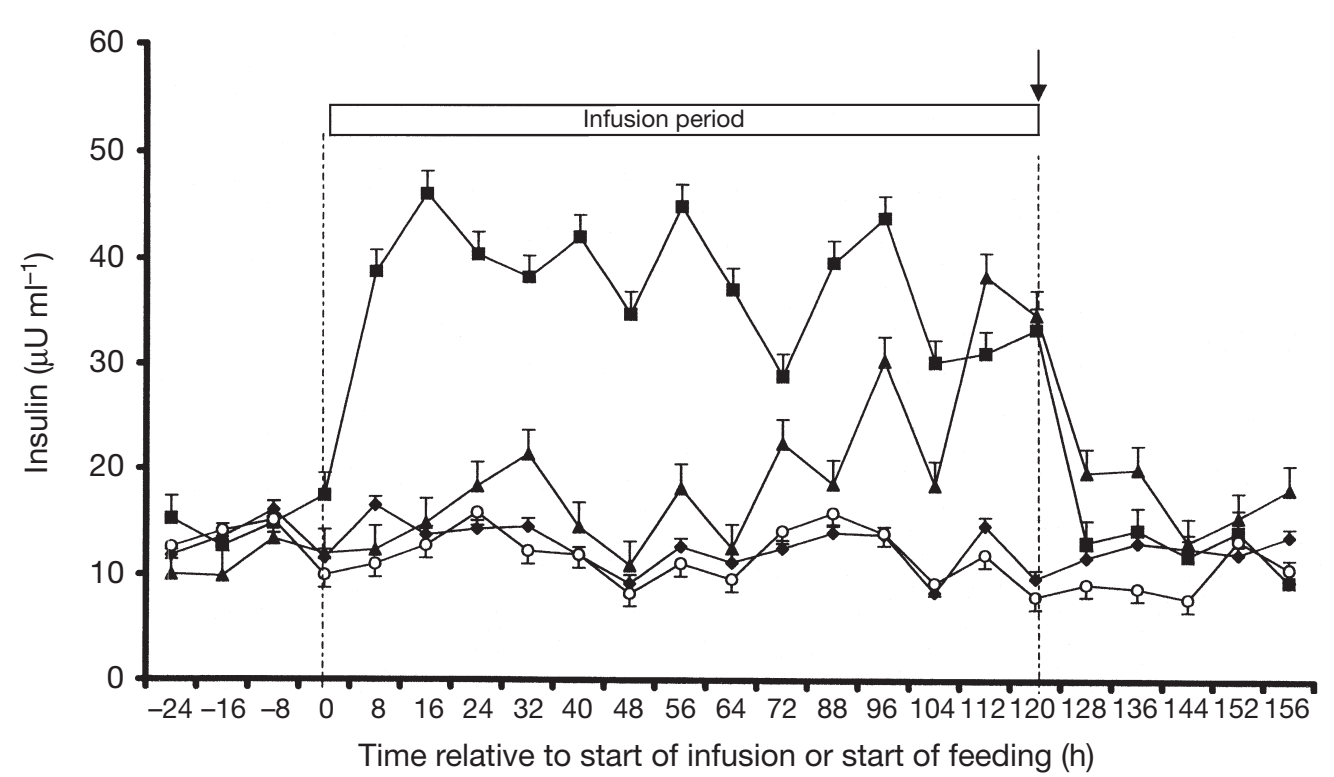

Fig. 3. The mean \pm SEM plasma concentration of insulin in anoestrous Merino ewes in which follicular growth was induced with GnRH. The ewes were infused with saline (control, $\diamond ; n=5$ ), glucose $\left(\boldsymbol{\square}, 50 \mathrm{mmol} \mathrm{h}^{-1} ; n=5\right)$ or glucosamine $\left(\bigcirc, 3.5 \mathrm{mmol} \mathrm{h}^{-1} ; n=5\right)$ or fed a supplement of lupin grain $\left(\boldsymbol{\Lambda}, 500 \mathrm{~g} \mathrm{day}^{-1} ; n=4\right)$ for 5 days until the time of progesterone pessary withdrawal (arrow). Animals were killed $156 \mathrm{~h}$ after the start of infusion or feeding.

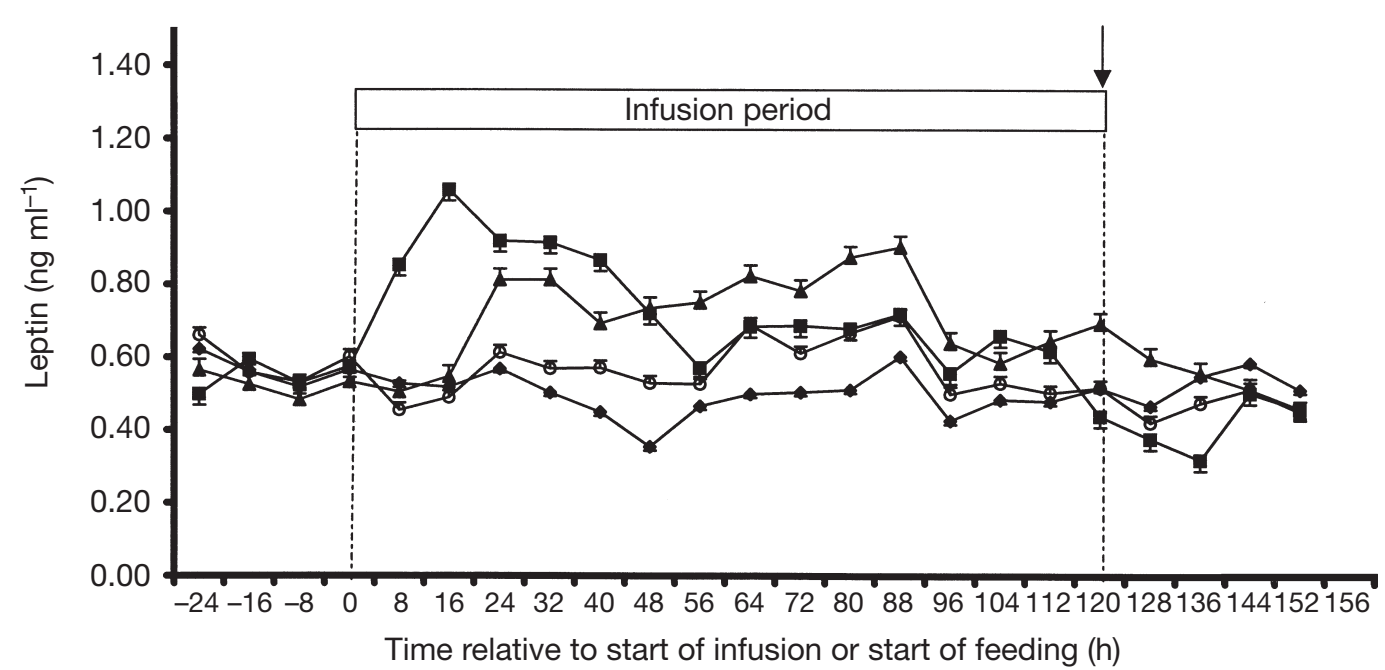

Fig. 4. The mean \pm SEM plasma concentration of leptin in anoestrous Merino ewes in which follicular growth was induced with GnRH. The ewes were infused with saline (control, $\bullet ; n=5$ ), glucose $(\boldsymbol{\square}$, $\left.50 \mathrm{mmol} \mathrm{h}^{-1} ; n=5\right)$ or glucosamine $\left(0,3.5 \mathrm{mmol} \mathrm{h}^{-1} ; n=5\right)$ or fed a supplement of lupin grain $(\boldsymbol{\Lambda}$, $\left.500 \mathrm{~g} \mathrm{day}^{-1} ; n=4\right)$ for 5 days until the time of progesterone pessary withdrawal (arrow). Animals were killed $156 \mathrm{~h}$ after the start of infusion or feeding.

found in 15 of 20 ewes; in ten of these ewes, the largest follicle was also aromatase-positive. The results of the present study also show that the concentration of oestrogen in the ovarian vein draining an ovary containing an aromatase-positive follicle was significantly higher than the concentration of oestrogen in the ovarian vein draining an ovary containing only aromatase-negative follicles. These data are in agreement with other reports demonstrating that: (i) the largest follicle is the principal source of ovarian venous oestradiol (Baird and Scaramuzzi, 1976); (ii) aromatase activity of granulosa cells and oestradiol concentration in follicular fluid are positively correlated in follicles $>3.5 \mathrm{~mm}$ in diameter (Monniaux, 1987); and (iii) aromatase activity is found principally in the granulosa cells of peri-ovulatory follicles in superovulated sheep (Lautinick et al., 1994). The results of the present study show that the 


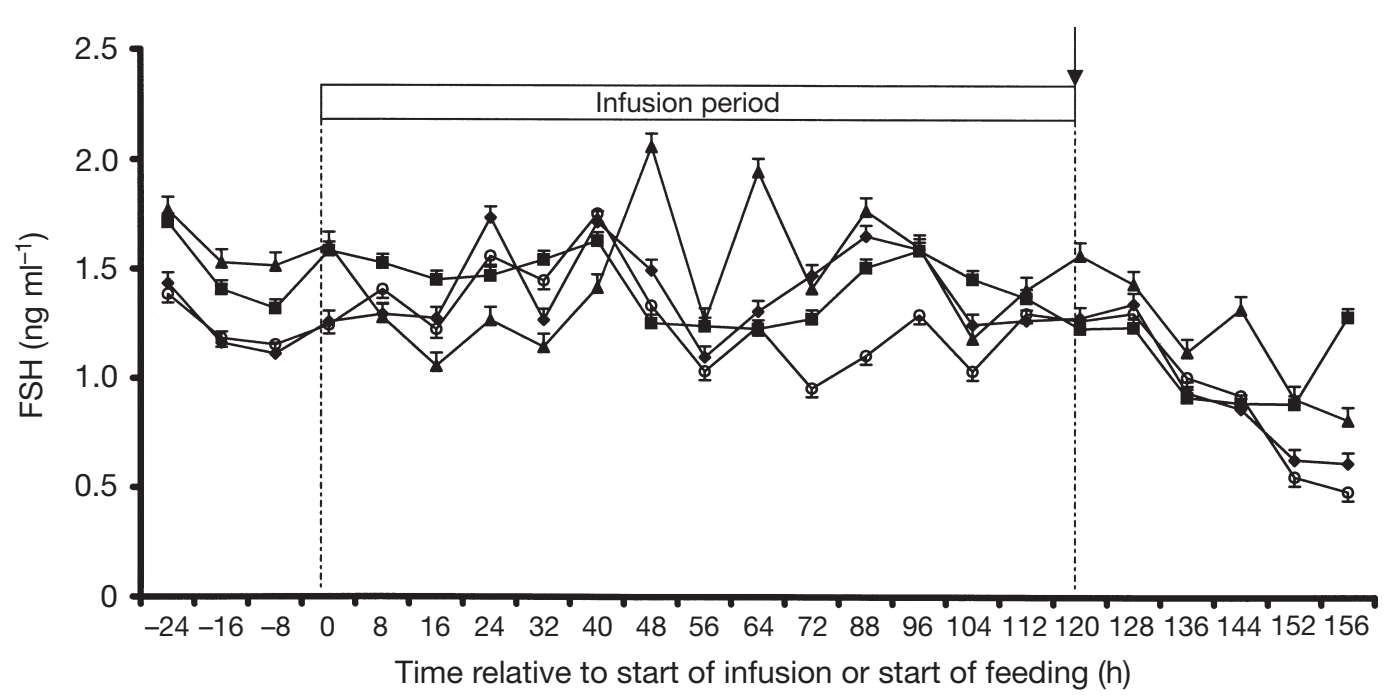

Fig. 5. The mean \pm SEM plasma concentration of follicle stimulating hormone $(\mathrm{FSH})$ in anoestrous Merino ewes in which follicular growth was induced with $\mathrm{GnRH}$. The ewes were infused with saline (control, $\bullet$; $n=5)$, glucose $\left(\boldsymbol{\square}, 50 \mathrm{mmol} \mathrm{h}^{-1} ; n=5\right)$ or glucosamine $\left(\bigcirc, 3.5 \mathrm{mmol} \mathrm{h}^{-1} ; n=5\right)$ or fed a supplement of lupin grain $\left(\boldsymbol{\Lambda}, 500 \mathrm{~g} \mathrm{day}^{-1} ; n=4\right)$ for 5 days until the time of progesterone pessary withdrawal (arrow). Animals were killed $156 \mathrm{~h}$ after the start of infusion or feeding.

number of large, potentially ovulatory follicles was always greater than the number of aromatase-positive follicles. Therefore, the number of large follicles is not necessarily a reliable indicator of potential ovulation rate because large follicles must also be oestrogenic if they are going to ovulate (Webb et al., 1989).

The following hypotheses were tested: (i) that short-term nutritional treatments that stimulate folliculogenesis will alter circulating plasma leptin concentrations; and (ii) that increased glucose or glucosamine acting through the hexosamine biosynthetic pathway will alter aromatase gene expression in the granulosa cells.

The results of the present study show that short-term nutritional supplementation can stimulate folliculogenesis and that the numbers of follicles $2-4 \mathrm{~mm}$ in diameter and $>6 \mathrm{~mm}$ were increased by nutritional supplementation. Follicles $>2.5 \mathrm{~mm}$ in diameter are normally considered to be capable of ovulating (Rhind and McNeilly, 1998). The data from the present study are in agreement with earlier results (Allen and Lamming, 1961), showing that ewes fed a high energy diet had increased numbers of follicles $2-3 \mathrm{~mm}$ in diameter. However, this is not a consistent observation and, in one study (Rhind and McNeilly, 1998), a high food intake increased the number of follicles $1.0-2.5 \mathrm{~mm}$ in diameter but not follicles $>2.5 \mathrm{~mm}$ in diameter. When ewes were fed lupin grain, the increase in ovulation rate was correlated with a greater number of follicles $>2 \mathrm{~mm}$ in diameter. Nottle et al. (1985) and Downing (1994) suggested that lupin grain supplementation decreased the number of follicles undergoing atresia. Increased energy supply did not affect the early stages of follicular development, but did increase ovulation rate by preventing atresia in follicles $2-3 \mathrm{~mm}$ in diameter without affecting the number of follicles $>3 \mathrm{~mm}$ in diameter (Haresign, 1981). Follicles $>6 \mathrm{~mm}$ in diameter were seen only in ewes given the nutritional supplement, and the diameter of the aromatase-positive follicles was increased by lupin feeding. These findings indicate that nutritional supplementation increases ovulation rate by preventing atresia in large dominant follicles.

The number of aromatase-positive follicles was not affected by the treatments. However, closer inspection of the data showed that the number of aromatase-positive follicles in the energy-supplemented animals was about twice the number in the control group. There have been consistent reports that nutritional supplementation increases the number of large follicles. For example, 600 or $1200 \mathrm{~g}$ of a mixture of $10 \%$ lupin grain in hammer milled oaten hay for 14 weeks increased the number of oestrogenic follicles and the total ovarian content of oestradiol in growing follicles (Boukhliq et al., 1996), and the increased ovulation rate observed when feeding grain supplements has been associated with a larger number of follicles $>4 \mathrm{~mm}$ in diameter (Howland et al., 1966).

One of the objectives of the present study was to examine the potential role of the hexosamine pathway as a nutrient-signalling pathway in the follicle. There is considerable data to show that the hexosamine pathway is a nutrient-signalling pathway in muscle and adipose tissue. Glucosamine is present in the follicular fluid of small and medium-sized follicles, but not in that of large follicles of buffalo (Boushehri et al., 1996). In the ovary, eCG stimulates the rapid uptake of glucosamine by the zona pellucida and increases its concentration in follicular fluid from large follicles, whereas hCG enhances glucosamine uptake by the theca and granulosa of preovulatory follicles (Fowler 
and Guttridge, 1987). Although these data show that glucosamine is present and active in the follicle, it is not directly concerned with its potential nutrient signalling role. The results of the present study indicate that glucosamine infusion stimulates folliculogenesis, as it increased the number of follicles of between 3 and $4 \mathrm{~mm}$ in diameter and, in this respect, mimicked the effect of glucose. Glucosamine infusion also tended to increase the number of aromatasepositive follicles and the number of follicles $>6 \mathrm{~mm}$ in diameter. Thus, glucosamine may be a nutrient-signalling pathway in the follicle, although further studies are required to confirm this tentative finding.

In addition to stimulating folliculogenesis, the nutritional supplements had a range of effects on circulating hormones. Lupin supplementation and glucose infusion both increased the plasma concentrations of insulin, indicating increased cellular uptake of glucose by follicles using the insulinmediated GLUT4 pathway (Williams et al., 2001). The effects of insulin on follicular cells include: (i) enhancement of glucose and amino acid metabolism; (ii) stimulation of cell proliferation and growth; (iii) stimulation and inhibition of follicular steroid secretion; and (iv) modulation of gonadotrophin receptor function (Allen et al., 1981; Savio et al., 1981; Rein and Schomberg, 1982; Poretsky et al., 1985; Veldhius et al., 1985; Davoren et al., 1986; Downing et al., 1999).

There is evidence that leptin provides a signal of nutritional status to the reproductive system, and is the long sought-after mediator of nutritional status. Leptin is produced in adipose tissue, which actively responds to nutritional and metabolic changes. Leptin can act as a metabolic signal to the reproductive system by direct actions on the follicle (Spicer and Francisco, 1997). There are leptin receptors in the human ovary (Greisen et al., 2000) and leptin can attenuate insulin-induced steroidogenesis of granulosa cells directly without affecting cell proliferation (Spicer and Francisco, 1997).

Leptin secretion is subject to both long-term and shortterm regulation. Glucose, pyruvate and insulin all act on rat adipocytes in vitro to stimulate release and to increase synthesis of leptin (Levy and Stevens, 2001). Leptin concentrations in sheep are not responsive to short-term $(<2 \mathrm{~h})$ changes in blood glucose or insulin (Kauter et al., 2000). The present results confirm that, in sheep, a longterm glucose infusion increased plasma leptin concentrations by $8 \mathrm{~h}$. The lupin supplement also increased plasma leptin concentrations but this effect was not observed until $24 \mathrm{~h}$ after the start of feeding. The results of the present study reveal some interesting temporal relationships among leptin, insulin and glucose. The leptin concentration was increased after either glucose infusion (increased by $8 \mathrm{~h}$ ) or lupin feeding (increased by $24 \mathrm{~h}$ ), but the increased concentration of leptin was not maintained despite the continued high concentration of glucose or insulin. Rats on high-fat diets may become resistant to leptin (Walder et al., 1999; El-Haschimi et al., 2000; Lin et al., 2000, 2001) and a similar mechanism in sheep would explain the present findings or indicate early signs of insulin resistance (Levy et al., 2000; Chillard et al., 2001). These results raise some questions about the interaction between insulin and glucose in the regulation of leptin secretion in ruminants.

In the present study, leptin had been at baseline concentrations for about $60 \mathrm{~h}$ before the ovaries were collected, indicating either a long-term effect of leptin on aromatase expression or, more probably, that a follicle, once selected, remains oestrogenic for at least $60 \mathrm{~h}$ (Campbell et al., 1995; Souza et al., 1996, 1997). The results of the present study in conjunction with other published information (Spicer, 2001) are consistent with the contention that leptin is a mediator of nutritional response on follicular function.

Glucosamine treatment did not alter the circulating concentrations of glucose, insulin or leptin. Nevertheless, glucosamine treatment did have effects on folliculogenesis and aromatase expression, indicating that its actions in follicular cells are intracellular. These findings are consistent with a proposed nutrient signalling role for glucosamine and the hexosamine pathway in the follicle, as occurs in skeletal muscle (Wang et al., 1998; Ukropec et al., 2001).

In conclusion, nutritional treatments have a direct stimulating action on folliculogenesis, which is independent of changes in circulating FSH. The effects were not the same across all three treatments and, furthermore, were observed at two different stages of folliculogenesis. The effect of lupin supplementation was mainly in large follicles $>6 \mathrm{~mm}$ in diameter, and this effect was not mimicked by infusion of either glucose or glucosamine. The effect of lupin grain supplementation is not completely mediated by increased insulin-mediated glucose uptake by the ovary. However, insulin-mediated glucose uptake did stimulate folliculogenesis, especially in medium-sized follicles 2-4 $\mathrm{mm}$ in diameter, an effect that was also observed in the glucosamine-infused ewes.

This work was supported by grants from The Wellcome Trust, The British Council, The University of Western Australia and CONACyT, Mexico. The authors would like to thank T. Leung and D. Howard (Royal Veterinary College), M. Blackberry, T. Sharma and P. Celli (University of Western Australia) for their assistance and Professor D. C. Wathes (Royal Veterinary College) for the $P_{450}$ Aromatase oligoprobe.

\section{References}

Adashi EY, Resnick CE and Twardzik DR (1987) Transforming growth factor-alpha attenuates the acquisition of aromatase activity by cultured rat granulosa cells Journal of Cell Biochemistry 33 1-13

Adashi EY, Resnick CE, Croft CS, May JV and Gospodarowicz D (1988) Basic fibroblast growth factor as a regulator of ovarian granulosa cell differentiation: a novel non-mitogenic role Molecular and Cellular Endocrinology 55 7-14

Allen WR and Lamming GE (1961) Nutrition and reproduction in the ewe Journal of Agricultural Science (Cambridge) 56 69-79

Allen WR, Nielsen-Hamilton MB and Hamilton RT (1981) Insulin and growth factors stimulate rapid post-translational changes in glucose transport in ovarian granulosa cells Journal of Cellular Physiology 108 $15-24$ 
Atkinson S and Adams NR (1988) Adrenal glands alter the concentration of oestradiol-17 beta and its receptor in the uterus of ovariectomized ewes Journal of Endocrinology 118 375-380

Baird DT and Scaramuzzi RJ (1976) The source of ovarian oestradiol and androstenedione in the sheep during the luteal phase Acta Endocrinologica (Copenhagen) 83 402-409

Bao B and Garverick HA (1998) Expression of steroidogenic enzyme and gonadotropin receptor genes in bovine follicles during ovarian follicular waves: a review Journal of Animal Science 76 1903-1921

Bindon BM, Blanc MR, Pelletier J, Terqui M and Thimonier J (1979) Periovulatory gonadotrophin and ovarian steroid patterns in sheep of breeds with differing fecundity Journal of Reproduction and Fertility $\mathbf{5 5}$ 15-25

Blache D, Tellam RL, Chagas LM, Blackberry MA, Vercoe PE and Martin GB (2000) Level of nutrition affects leptin concentrations in plasma and cerebrospinal fluid in sheep Journal of Endocrinology 165 625-637

Boukhliq R, Adams NR and Martin GB (1996) Effect of nutrition on the balance of production of ovarian and pituitary hormones in ewes Animal Reproduction Science 45 59-70

Boushehri I, Yadav MC and Meur SK (1996) Characteristics of proteoglycans of buffalo ovarian follicular fluid during maturation of follicles Indian Journal of Biochemistry and Biophysics 33 213-217

Cahill LP, Saumande J, Ravault JP, Blanc M, Thimonier J, Mariana JC and Mauleon P (1981) Hormonal and follicular relationships in ewes of high and low ovulation rates Journal of Reproduction and Fertility $\mathbf{6 2}$ 141-150

Campbell BK, Scaramuzzi RJ and Webb R (1995) Control of antral follicle development and selection in sheep and cattle Journal of Reproduction and Fertility Supplement 49 335-350

Chilliard Y, Bonnet M, Delavaud C, Faulconnier Y, Leroux C, Djiane J and Bocquier F (2001) Leptin in ruminants. Gene expression in adipose tissue and mammary gland, and regulation of plasma concentration Domestic Animal Endocrinology 21 271-295

Daniels MC, Kansal P, Smith TM, Paterson AJ, Kudlow JE and McClain DA (1993) Glucose regulation of transforming growth factor-alpha expression is mediated by products of the hexosamine biosynthesis pathway Molecular Endocrinology 7 1041-1048

Davoren JB, Kasson BG, Li CH and Hsueh AJW (1986) Specific insulin-like growth factor (IGF) I and II-binding sites on rat granulosa cells: relation to IGF action Endocrinology 119 2155-2162

Downing JA (1994) Interactions of Nutrition and Ovulation Rate in Ewes PhD Thesis, Macquarie University

Downing JA and Scaramuzzi RJ (1991) Nutrient effects on ovulation rate, ovarian function and the secretion of gonadotrophic and metabolic hormones in sheep Journal of Reproduction and Fertility Supplement $4 \mathbf{3}$ 209-227

Downing JA, Joss J and Scaramuzzi RJ (1995a) Ovulation rate and the concentrations of gonadotrophins and metabolic hormones in ewes infused with glucose during the late luteal phase of the oestrous cycle Journal of Endocrinology 147 403-410

Downing JA, Joss J and Scaramuzzi RJ (1995b) A mixture of the branched chain amino acids, leucine, isoleucine and valine, increases ovulation rate in ewes when infused during the late luteal phase of the oestrous cycle: an effect that may be mediated by insulin Journal of Endocrinology 145 315-323

Downing JA, Joss J, Connell P and Scaramuzzi RJ (1995c) Ovulation rate and the concentrations of gonadotrophic and metabolic hormones in ewes fed lupin grain Journal of Reproduction and Fertility 103 137-145

Downing JA, Joss J and Scaramuzzi RJ (1999) The effect of a direct arterial infusion of insulin and glucose on the ovarian secretion rates of androstenedione and oestradiol in ewes with an autotransplanted ovary Journal of Endocrinology $163531-541$

Driancourt MA, Philipon P, Locatelli A, Jacques E and Webb R (1988) Are differences in FSH concentrations involved in the control of ovulation rate in Romanoff and île-de-France ewes? Journal of Reproduction and Fertility 83 509-516

El-Haschimi K, Pierroz DD, Hileman SM, Bjorbaek C and Flier JS (2000) Two defects contribute to hypothalamic leptin resistance in mice with diet-induced obesity Journal of Clinical Investigation 105 1827-1832
Findlay JK and Cumming IA (1976) FSH in the ewe: effects of season, live weight and plane of nutrition on plasma FSH and ovulation rate Biology of Reproduction 15 335-342

Fowler RE and Guttridge K (1987) An autoradiographic study using $[3 \mathrm{H}]$ glucosamine of gonadotrophin regulation of proteoglycan and glycoprotein synthesis in developing mouse follicles Journal of Reproduction and Fertility $\mathbf{8 1} 415-426$

Gospodarowicz D and Bialecki H (1979) Fibroblast and epidermal growth factors are mitogenic agents for cultured granulosa cells of rodent, porcine and human origin Endocrinology 104 757-764

Gospodarowicz D and Birdwell CR (1977) Effects of fibroblast and epidermal growth factors on ovarian cell proliferation in vitro. I. Characterization of the response of granulosa cells to FGF and EGF Endocrinology $1001108-1120$

Greisen S, Ledet T, Moller N, Jorgensen JO, Christiansen JS, Petersen K and Ovensen P (2000) Effects of leptin basal and FSH stimulated steroidogenesis in human granulosa luteal cells Acta Obstetrica et Gynecologica Scandinavica 79 931-935

Haresign W (1981) The influence of nutrition on reproduction in the ewe. I. Effects on ovulation rate, follicle development and luteinizing hormone release Animal Production 32 197-202

Hinshelwood MM, Corbin CJ, Tsang PAW and Simpson ER (1993) Isolation and characterization of a complementary deoxyribonucleic acid insert encoding bovine aromatase cytochrome P450 Endocrinology 133 1971-1977

Howland BE, Kirkpatrick RL, Pope AL and Casida LE (1966) Pituitary and ovarian function in ewes fed on two nutritional levels Journal of Animal Science 25 716-721

Ingvartsen KL and Boisclair YR (2001) Leptin and the regulation of food intake, energy homeostasis and immunity with special focus on periparturient ruminants Domestic Animal Endocrinology 21 215-250

Kauter K, Ball M, Kearney P, Tellam R and McFarlane JR (2000) Adrenaline, insulin and glucagon do not have acute effects on plasma leptin levels in sheep: development and characterization of an ovine leptin ELISA Journal of Endocrinology 166 127-135

Landau S, Bor A, Leibovich H, Zoref Z, Nistan Z and Madar Z (1995) The effect of ruminal starch degradability in the diet of Booroola crossbred ewes on induced ovulation rate and prolificacy Animal Reproduction Science 38 97-108

Lautinik J, Kolodzieyski L, Elias V, Hyttel P, Osawa Y and Sirotkin A (1994) Immunocytochemical localization of aromatase in the ovary of superovulated cattle, pigs and sheep Acta Veterinaria Scandinavica 35 185-191

Leung ST (1997) The Regulation of Oxytocin Receptor Expression in the Reproductive Tract of Sheep During Pregnancy PhD Thesis, University of London

Leung ST, Wathes DC, Young IR and Jenkin G (1999) Effect of labour induction on the expression of oxytocin receptor, cytochrome P450 aromatase, and estradiol receptor in the reproductive tract of the latepregnant ewe Biology of Reproduction $60814-820$

Levy JR and Stevens W (2001) The effects of insulin, glucose and pyruvate on the kinetics of leptin secretion Endocrinology 142 3558-3562

Levy JR, Lesko J, Krieg RJ, Jr, Adler RA and Stevens W (2000) Leptin responses to glucose infusions in obesity-prone rats American Journal of Physiology, Endocrinology and Metabolism 279 E1088-1096

Lin L, Martin R, Schaffhauser AO and York DA (2001) Acute changes in the response to peripheral leptin with alteration in the diet composition American Journal of Physiology: Regulatory Integrative and Comparative Physiology 280 R504-509

Lin S, Thomas TC, Storlien LH, and Huang XF (2000) Development of high fat diet-induced obesity and leptin resistance in $\mathrm{C} 57 \mathrm{Bl} / 6 \mathrm{~J}$ mice International Journal of Obesity and Relative Metabolic Disorders 24 639-646

Lindsay DR, Martin GB and Williams IH (1991) Nutrition and reproduction In Reproduction in Domesticated Animals: World Animal Science Series pp 459-491 Ed. GJ King. Elsevier Science Publishers, Amsterdam

Lobb DK and Dorrington J (1992) Intraovarian regulation of follicular development Animal Reproduction Science 28 343-354

McClain DA, Paterson AJ, Roos MD, Wei X and Kudlow JE (1992) Glucose 
and glucosamine regulate growth factor gene expression in vascular smooth muscle cells Proceedings National Academy of Sciences USA $898150-8154$

Monget P and Monniaux D (1995) Growth factors and the control of folliculogenesis Journal of Reproduction and Fertility Supplement $\mathbf{4 9}$ 321-333

Monniaux D (1987) Short-term effects of FSH in vitro on granulosa cells of individual sheep follicles Journal of Reproduction and Fertility $\mathbf{7 9}$ 505-515

Monniaux D, Pisselet C and Fontaine J (1994) Uncoupling between proliferation and differentiation of ovine granulosa cells in vitro. Journal of Endocrinology 142 497-510

Nottle MB, Armstrong DT, Setche LL and Seamark RF (1985) Lupin feeding and folliculogenesis in the Merino ewe Proceedings of the Nutrition Society of Australia 10 Abstract 145

Nottle MB, Hynd PI, Seamark RF and Setchell BP (1988) Increases in ovulation rate in lupin-fed ewes are initiated by increases in protein digested post-ruminally Journal of Reproduction and Fertility $\mathbf{8 4}$ $563-566$

Nottle MB, Seamark RF and Setchell BP (1990) Feeding lupin grain for six days prior to a cloprostenol-induced luteolysis can increase ovulation rate in sheep irrespective of when in the oestrous cycle supplementation commences Reproduction, Fertility and Development 2 189-192

Perks MC (1994) The Insulin-Like Growth Factors in the Ovine Ovary PhD Thesis, University of Bristol

Poretsky LF, Grigorescu F, Seibrl M, Moses AC and Flier JS (1985) Distribution and characterization of insulin and insulin-like growth factor 1 receptors in normal human ovary Journal of Clinical Endocrinology and Metabolism 61 728-734

Rein MS and Schomberg DW (1982) Characterization of insulin receptors on porcine granulosa cells Biology of Reproduction 26 Supplement $\mathbf{1}$ Abstract 113

Rhind SM and McNeilly AS (1986) Follicle populations, ovulation rates and plasma profiles of $\mathrm{LH}, \mathrm{FSH}$ and prolactin in Scottish Blackface ewes in high and low body condition Animal Reproduction Science 10 105-115

Rhind SM and McNeilly AS (1998) Effects of level of food intake on ovarian follicle number, size and steroidogenic capacity in the ewe Animal Reproduction Science $\mathbf{5 2}$ 131-138

Rhind SM, Martin GB, McMillen S, Tsonis SCG and McNeilly AS (1989) Effect of level of food intake of ewes on the secretion of luteinizing hormone ( $\mathrm{LH})$ and follicle stimulating hormone (FSH) and on the pituitary response to gonadotropin-releasing hormone $(\mathrm{GnRH})$ in ovariectomized ewes Journal of Endocrinology 121 325-330

Roos MD, Han IO, Paterson AJ and Kudlow JE (1996) Role of glucosamine synthesis in the stimulation of TGF-alpha gene transcription by glucose and EGF American Journal of Physiology 270 C803-C811

SAS (1995) System for Windows, Release 6.12 SAS Institute, Cary, NY

Savio N, Lui GM, Laherty R and Gospodarowicz D (1981) Factors controlling proliferation and progesterone production by bovine granulosa cells in serum-free medium Endocrinology 109 409-420

Scaramuzzi RJ, Adams NR, Baird DT et al. (1993) A model for follicle selection and the determination of ovulation rate in the ewe Reproduction, Fertility and Development 5 459-478

Skinner MK and Coffey RJ, Jr (1988) Regulation of ovarian cell growth through the local production of transforming growth factor-alpha by theca cells Endocrinology 123 2632-2638
Skinner MK, Kesi-Oja J, Osteen KG and Moses HL (1987) Ovarian thecal cells produce transforming growth factor $\beta$ which can regulate granulosa cell growth Endocrinology 121 786-792

Souza CJH, Campbell BK and Baird DT (1996) Follicular dynamics and ovarian steroid secretion in sheep during anoestrus Journal of Reproduction and Fertility 108 101-106

Souza CJH, Campbell BK and Baird DT (1997) Follicular dynamics and ovarian steroid secretion in sheep during the follicular and early luteal phase of the estrous cycle Biology of Reproduction 56 483-488

Spicer LJ (2001) Leptin: a possible metabolic signal affecting reproduction Domestic Animal Endocrinology 21 251-270

Spicer JL and Francisco CC (1997) The adipose obese gene product leptin: evidence of a direct inhibitory role in ovarian function Endocrinology $1383374-3379$

Tindal JS, Knaggs GS, Hart IC and Blake LA (1978) Release of growth hormone in lactating and non-lactating goats in relation to behaviour, stages of sleep, electroencephalographs, environmental stimuli and levels of prolactin, insulin, glucose and free fatty acids in the circulation Journal of Endocrinology 76 333-346

Ukropec J, Sebokova E and Klimes I (2001) Nutrient sensing, leptin and insulin action Archives in Physiology and Biochemistry 109 38-51

Veldhius JD, Furlanetto RW, Juchter P, Garmwey J and Veldhius P (1985) Tropic actions of human somatomedin C/insulin-like growth factor I on ovarian cells: in vitro studies with swine granulosa cells Journal of Biological Chemistry 262 7658-7664

Walder K, Lewandowski P, Morton G, Sanigorski A, de Silva A, Zimmet P and Collier GR (1999) Leptin resistance in a polygenic, hyperleptinemic animal model of obesity and NIDDM: Psammomys obesus. International Journal of Obesity Related Metabolic Disorders 23 83-89

Wang J, Liu R, Hawkins M, Barzilai N and Rosseti L (1998) A nutrientsensing pathway regulates leptin gene expression in muscle and fat Nature (London) 393 684-688

Wathes DC, Smith HF, Leung ST, Stevenson KR, Meier S and Jenkin G (1996) Oxytocin receptor development in ovine uterus and cervix throughout pregnancy and at parturition as determined by in situ hybridization analysis Journal of Reproduction and Fertility 106 23-31

Webb R, Baxter G, McBride D, Nordblom GD and Shaw MP (1985) The measurement of testosterone and oestradiol- 17 beta using iodinated tracers and incorporating an affinity chromatography extraction procedure Journal of Steroid Biochemistry 23 1043-1051

Webb R, Gauld IK and MA Draincourt (1989) Morphological and functional characteristics of large antral follicles in three breeds of sheep with different ovulation rates Journal of Reproduction and Fertility $\mathbf{8 7}$ 243-255

Williams SA, Blache D, Martin GB, Foot R, Blackberry MA and Scaramuzzi RJ (2001) Effect of nutritional supplementation on quantities of glucose transporters 1 and 4 in sheep granulosa and theca cells Reproduction 122 947-956

Received 8 May 2002.

First decision 12 July 2002.

Revised manuscript received 30 July 2002.

Accepted 2 August 2002. 